\title{
Composition proximate, bioactive compounds and antioxidant capacity of Butia capitata
}

\author{
Maria Cristina de Albuquerque BARBOSA ${ }^{1}$, Queila da Silva ROSA ${ }^{1}$, Leandro de Morais CARDOSO ${ }^{1}$, \\ Antônio Frederico de Freitas GOMIDES², Luiz Cláudio de Almeida BARBOSA³, \\ Helena Maria Pinheiro SANT’ANNA ${ }^{4}$, Soraia Silva PINHEIRO ${ }^{4}$, Maria do Carmo Gouveia PELUZIO ${ }^{4}$, \\ Reinaldo Duque Brasil Landulfo TEIXEIRA ${ }^{2}$, Maria Anete Santana VALENTE ${ }^{1 *}$ (c)
}

\begin{abstract}
Butia capitata, native to the Brazilian cerrado, is underutilized for human consumption. The objective was to determine the physical characteristics of the fruit, centesimal composition, bioactive and antioxidant activity. Fruits obtained in Montes Claros, Minas Gerais, Brazil. Diameter, height and weight were evaluated. The moisture was analyzed by gravimetry after oven drying, ashes by calcining in a muffle furnace, proteins by the Kjeldahl method, gravimetric lipids after extraction in ethyl ether, carbohydrates by difference and total energy value by conversion factors. Vitamin C, E and carotenoids were analyzed by HPLC, minerals by inductively coupled plasma atomic absorption spectrometry, Folin Ciocalteu solution phenolic compounds, anthocyanins by spectrophotometry and antioxidant capacity by the Radical DPPH. The fruits presented good pulp yield (68.59\%), which has a high lipid content $\left(3.42 \mathrm{~g} .100 \mathrm{~g}^{-1}\right)$ and total energy $\left(83.34 \mathrm{kcal} 100 \mathrm{~g}^{-1}\right)$. The pulp contains $ß$-carotene $\left(8.56 \mathrm{mg} .100 \mathrm{~g}^{-1}\right)$, vitamin $\mathrm{E}\left(121.07 \mathrm{mcg} .100 \mathrm{~g}^{-1}\right)$ and high concentrations of vitamin C (53.57 mg. $\left.100 \mathrm{~g} \mathrm{~g}^{-1}\right)$, total phenolics $\left(493,6 \mathrm{mg} .100 \mathrm{~g}^{-1}\right)$ and copper $\left(1.80 \mathrm{mg} .100 \mathrm{~g}^{-1}\right)$. Almond has a high value of total energy $\left(457.72 \mathrm{kcal} .100 \mathrm{~g} \mathrm{~g}^{-1}\right)$, vitamin E $\left(1594.39 \mathrm{mcg} .100 \mathrm{~g}^{-1}\right)$ and minerals $\mathrm{Cu}\left(2.40 \mathrm{mg} 100 \mathrm{~g}^{-1}\right)$ and Mo $\left(0.9 .100 \mathrm{~g}^{-1}\right)$. The pulp is a source of carotenoids, vitamin C, copper and total phenolics, both natural antioxidants.
\end{abstract}

Keywords: physical characterization; proximate composition; phenolic compounds; sour coconut.

Practical Application: Butiá, from a native species of the savana, is a relevant option for consumption. Our data show that this fruit is a source of nutrients and bioactive compounds, important for growth and child development and protection against diseases.

\section{Introduction}

Fruit consumption by humans is recognized to be important because it provides nutrients and bioactive compounds that contribute to reducing the risk of developing various diseases, including non-communicable diseases and chronic diseases (Slavin \& Lloyd, 2012). In this context, several fruits underutilized in human food have been receiving special attention from the scientific community as a source of nutrients, bioactive compounds and due to their nutritional and functional properties.

Brazil has a great variety of native fruit species still little explored, even being sources of nutritious food for some populations. In addition, these fruits have great economic and social importance, since they are commercialized/consumed in natura or in the form of products elaborated by the population or by small agroindustries (Magalhães et al., 2008; Schwartz et al., 2010). Among these fruits, we highlight the Butia capitata, a palm native to the Brazilian Cerrado known as coquinho azedo, butiá, coquinho, coco-cabeçudo, butiá-azedo or butiazeiro (Vieira et al., 2006).
The fruits of the Butia capitata are arranged in bunches (Schwartz et al., 2010). In endemic areas, the fruits are of great economic importance since they are marketed by small producers' cooperatives. In these localized, its pulp is consumed of several forms, including in natura or in the form of ice cream, juice, liquor and jellies; their almonds are used in the manufacture of sweets, breads, biscuits and oils (Carvalho, 2007; Vieira et al., 2006). However, in other regions, the use of this fruit of the butiá in the feeding is still little diffused.

The fruits of the Butia capitata in the region of Minas Gerais are potentially nutritious, being their source source of vitamins C and provitamin A, dietary fiber (Faria et al., 2008a) and oils (Lopes et al., 2012). Studies on the nutritional composition, especially of vitamins and minerals and the identification of bioactive compounds are still very incipient.

In view of the above, this work aimed to determine the physical characteristics, the centesimal and bioactive composition and antioxidant capacity of the fruit of the sour coconut. 


\section{Materials and methods}

\subsection{Sample obtention}

Butia fruits (Butia capitata) were collected in the rural area of the municipality of Montes Claros, Minas Gerais state, Brazil.

Fruits with full physiological maturity were collected after naturally falling from the trees. The collection area was divided into sub-areas for the acquisition of three repetitions and $5.0 \mathrm{~kg}$ of fruits were collected in each sub-area. Samples were transported overland from the collection site to the laboratory in polystyrene boxes, up to 36 hours after collection.

The fruits were washed under tap water to remove dirt and then dried with paper towels. Pulp of the Butia (exocarp and mesocarp) was manually separated from the rest of the fruit (endocarp and kernel) with the aid of a spatula, while the kernel was broken with the aid of a hammer and spatula, separating it from the fruit endocarp and mesocarp.

\subsection{Physical characterization}

The physical analyzes were performed on 30 fruits, with height and diameter gauging using a pachymeter (Western). The mass of the fruits (MF), pulp (MP), seed (DM) and almond (MA) were obtained by individual direct weighing in analytical balance (Gehaka). The yields of pulp + bark and of almonds were calculated using equations $(\mathrm{MP} / \mathrm{MF}) \times 100$ and $(\mathrm{MA} / \mathrm{MF}) \times 100$.

\subsection{Centesimal composition}

The chemical analyzes on the pulp + bark and the almond were carried out in triplicate. The moisture contents, ashes, proteins and lipids were determined (Association of Official Analytical Chemists, 1998), the carbohydrate content being obtained by difference. The total energetic value of the edible fractions was estimated considering the conversion factors of $4 \mathrm{kcal} \mathrm{g}^{-1}$ of protein or carbohydrate and $9 \mathrm{kcal} \mathrm{g}^{-1}$ of lipid (Brasil, 2003).

\subsection{Vitamin $C$, vitamin $E$ and carotenoids}

For extraction and analysis of ascorbic acid (AA), about $5 \mathrm{~g}$ of pulp was homogenized in $15 \mathrm{~mL}$ of extractive solution (3\% metaphosphoric acid, $8 \%$ acetic acid, H 2 SO $4(0.3 \mathrm{~N})$ and $1 \mathrm{mM}$ EDTA). The obtained extract was vacuum filtered and diluted with deionized water and analyzed by High Performance Liquid Chromatography (HPLC), with diode array detection (DAD) (Shimadzu UV-VIS ${ }^{\circledast}$, Kyoto, Japan). The analyzes were performed from the injection of $50 \mu \mathrm{L}$ of the previously filtered extracts. Chromatographic conditions included: Lichrospher $100 \mathrm{RP}-18(250 \times 4 \mathrm{~mm}, 5 \mu \mathrm{m})$ column coupled to Phenomenex ODS-C18 guard column $(4 \mathrm{~mm} \times 3 \mathrm{~mm})$; detection at $450 \mathrm{~nm}$; flow of the mobile phase of $1.0 \mathrm{~mL} / \mathrm{min}$ (Campos et al., 2009).

The content of eight isomers $(\alpha-, \beta-, \gamma$ - and $\delta$-tocopherol and tocotrienol) of vitamin $\mathrm{E}$ was investigated. For extraction, five grams of sample were added with $10.0 \mathrm{~mL}$ of isopropanol; $1.0 \mathrm{~mL}$ of hexane containing $0.05 \% \mathrm{BHT}$ and $5 \mathrm{~g}$ of anhydrous sodium sulfate and then homogenized in ultra-turrax (IKA, model T25). Then, the dispersion was filtered and the extract concentrated on a rotary evaporator $\left(70 \pm 1^{\circ} \mathrm{C}\right)$ and resuspended in a solvent mixture. The analyzes of the vitamin $\mathrm{E}$ isomers were performed in a CLAE system with fluorescence detector (Shimadzu). Chromatographic conditions included: LiChrosorb chromatography column (Si60 Phenomenex $250 \times 4 \mathrm{~mm}, 5 \mu \mathrm{m}$ ), mobile phase hexane: isopropanol: glacial acetic acid (98.9: 0.6: $0.5)$, mobile phase flow $1 \mathrm{~mL} / \mathrm{min}$. The total vitamin $\mathrm{E}$ content was calculated by the sum of the vitamin $\mathrm{E}$ isomers identified (Guinazi et al., 2009).

For extraction of carotenoids ( $\alpha$-carotene, $\beta$-carotene, $\beta$-cryptoxanthin and lycopene), 5 grams of sample were added with $60 \mathrm{~mL}$ of cooled acetone, homogenized, and vacuum filtered. Then, the carotenoids present in the filtrate were transferred to petroleum ether $(50.0 \mathrm{~mL})$. The extract was concentrated to $25 \mathrm{~mL}$ on a rotary evaporator $\left(35 \pm 1^{\circ} \mathrm{C}\right.$ ) (Rodriguez-Amaya et al., 2008). The HPLC analysis was performed by HPLC-DAD (Shimadzu) and included the following chromatographic conditions (Pinheiro-Sant'Ana et al., 1998): Phenomenex Gemini RP-18 chromatography column $(250 \times 4.6 \mathrm{~mm}, 5 \mu \mathrm{m})$, coupled to Phenomenex ODS-C18 guard column $(4 \mathrm{~mm} \times 3 \mathrm{~mm})$, detection at $450 \mathrm{~nm}$, mobile phase methanol: ethyl acetate: acetonitrile (70:20:10, v/v/v), mobile phase $1.7 \mathrm{~mL} / \mathrm{min}$ (Pinheiro-Sant'An a et al., 1998).

The identification of the compounds (vitamin C, vitamin $\mathrm{E}$ and carotenoids) was performed comparing the retention time of the peaks obtained for the sample and the standards. In addition, carotenoids and ascorbic acid were identified by the absorption spectrum and homologues of vitamin E by co-chromatography. Compounds were quantified using analytical curves with R2 ranging from 0.9972 to 0.9991 .

\subsection{Minerals}

The acid digestion of the samples for mineral analysis was performed using previously demineralized materials and glassware. About $1 \mathrm{~g}$ of lyophilized sample was transferred to a digestion tube and added with $10 \mathrm{~mL}$ of nitric acid. The mixture was kept at room temperature for $24 \mathrm{~h}$ and then heated at $50{ }^{\circ} \mathrm{C}$ for $6 \mathrm{~h}$ and $120^{\circ} \mathrm{C}$ for $14 \mathrm{~h}$. The tubes were cooled to room temperature and the digested solution completed to $25 \mathrm{~mL}$ with deionized water. The minerals and trace elements contents were analyzed by atomic emission spectrometry with inductively coupled plasma (Optima 3300 DV, Perkin Elmer). The elements were quantified in the samples against an external standard consisting of standard multielement solutions. The analytical curves were obtained using six solutions with different concentrations (Ekholm et al., 2007).

\subsection{Total phenolic compounds, anthocyanins and antioxidant capacity}

The extracts for analysis of total phenolic compounds, anthocyanin and total antioxidant capacity were prepared by suspending $10 \mathrm{~g}$ of sample in $20 \mathrm{~mL}$ of $0.01 \% \mathrm{HCl}$ in methanol $(\mathrm{v} / \mathrm{v})$. The suspension was stirred for $2 \mathrm{~h}$ in the dark and then centrifuged at $12,000 \mathrm{~g}$ for $15 \mathrm{~min}$ at $40{ }^{\circ} \mathrm{C}$. The residue was washed twice with $10 \mathrm{~mL}$ of acidified methanol and centrifuged. The supernatant was vacuum filtered, concentrated on a rotary 
evaporator at $30{ }^{\circ} \mathrm{C}$. The concentrate was diluted with $10 \mathrm{~mL}$ of acidified deionized water $(0.01 \% \mathrm{v} / \mathrm{v} \mathrm{HCl})$.

Phenolic compounds using 20\% Folin Ciocalteu solution and $7.5 \%$ sodium carbonate solution. The absorbance after the reactions was read in a spectrophotometer (Thermoscientific, Evolution 60S, USA) at $765 \mathrm{~nm}$. Quantification was performed from the standard curve of gallic acid, and the results were expressed in mg equivalents of gallic acid per gram of sample.

Total anthocyanins were determined by the differential pH method (Fuleki \& Francis, 1968), with modifications. The anthocyanin fraction was in the extracts of 513 and $700 \mathrm{~nm}$ in spectrophotometer (Shimadzu UV-VIS ${ }^{\oplus}$, Kyoto, Japan).

The antioxidant capacity was determined by the DPPH (1,1-diphenyl-2-picrylhydrazyl) method, with absorbance reading at $517 \mathrm{~nm}$ in a spectrophotometer (Shimadzu UV-VIS ${ }^{\circledast}$, Kyoto, Japan). Quantification was performed using a standard trolox solution curve $(50-100 \mu \mathrm{mol} / \mathrm{L})$, with the results expressed in trolox equivalent ( $\mu \mathrm{mol} / \mathrm{g})$ of the sample (Bloor, 2001).

\section{Results and discussion}

\subsection{Physical characterization}

The fruit of butia is an oval drupe, with pulp of yellowish color, adhered to the bark and the seed. Each fruit may contain one to two almonds (Figure 1).

The fruit mass was $6.24 \mathrm{~g}$, with a pulp yield of $67.33 \%$, being observed a great variation in these parameters (Table 1). The pulp yield is an important parameter for the economical feasibility study of the use of this fruit for the processing of pulp for juices, jellies, sweets and ice creams (Cabral et al., 2014), and this fruit is feasible for this purpose. The fruit mass, yield and pulp mass were lower than those observed by other authors who reported fruit weight between $8.02 \mathrm{~g}$ and $13.71 \mathrm{~g}$ (Sganzerla, 2010; Schwartz et al., 2010; Moura et al., 2010). The pulp yield of $70.97 \%$ described by Sganzerla (2010) was higher than described in the present study.

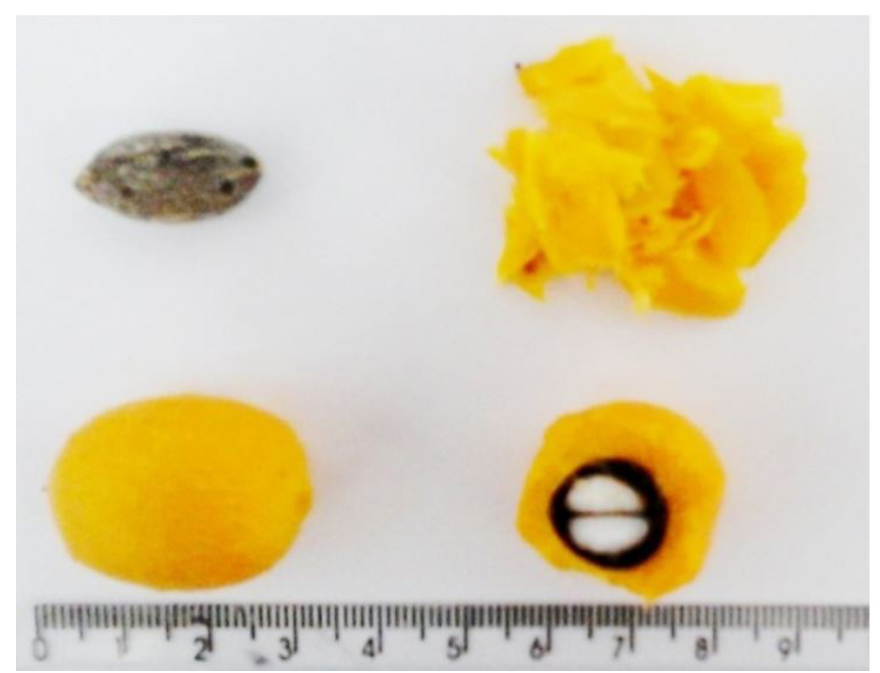

Figure 1. Photographic representation of fruits of the butiá (Butia capitata).
The average diameter of the fruit was $1.87 \mathrm{~cm}$, according to Hoffmann et al. (2014), the diameter of the fruits varies from 1.7 to $4.2 \mathrm{~cm}$, being a good indicator of yield. In this work, the diameter of the fruits was lower than those described by Schwartz et al. (2010) and Moura et al. (2010) $(2.11 \mathrm{~cm}$ and $2.75 \mathrm{~cm}$, respectively), the diameter of which differs significantly between fruit crops (Schwartz et al., 2010). The height of the fruit was $2.64 \mathrm{~cm}$, similar to that observed by Moura et al. (2010) $(2.69 \mathrm{~cm})$.

\subsection{Centesimal composition}

The moisture and ash contents (Table 2) are within the ranges from $84.99 \%$ to $92.77 \%$ and from $0.25 \%$ to $0.9 \%$ observed by Sganzerla (2010), Pereira et al. (2013), Lopes et al. (2012) and Moura et al. (2010) on fruits from different growing sites. The content of carbohydrates, the main nutrient identified in the butiá pulp, was similar to those observed by Sganzerla (2010) (12.11\%) and by Faria et al. (2008a) (10.8\%). The lipid content in the butia pulp was higher than that described by Sganzerla (2010), Lopes et al. (2012), Pereira et al. (2013), who observed from $0.11 \%$ to $2,8 \%$. The presence of high levels of unsaturated fatty acids (24\%) and high levels of oleic and linoleic fatty acids, essential for human consumption (Lopes et al., 2012; Peralta et al.

Table 1. Physical characteristics of fruits of the butiá (Butia capitata).

\begin{tabular}{lccc}
\hline \multirow{2}{*}{ Variables } & Media $^{\mathrm{a}} \pm \mathrm{SD}^{\mathrm{b}}$ & \multicolumn{2}{c}{ Amplitude } \\
\cline { 3 - 4 } & & Minimum & Maximum \\
\hline Diameter (cm) & $1.87 \pm 0.26$ & 1.4 & 2.3 \\
Height (cm) & $2.64 \pm 0.19$ & 2 & 2.9 \\
Almond number & $1.20 \pm 0.41$ & 1 & 2 \\
Mass (g) & & & \\
Fruit & $6.24 \pm 1.78$ & 3.47 & 8.86 \\
Pulp/bark & $4.28 \pm 1.45$ & 1.97 & 6.33 \\
Seeds & $1.68 \pm 0.32$ & 1.13 & 2.46 \\
Peel (Seed) & $1.19 \pm 0.21$ & 0.79 & 1.62 \\
Almond & $0.45 \pm 0.11$ & 0.28 & 0.76 \\
Almond yield (\%) & & & \\
Pulp yield (\%) & $68.59 \pm 5.55$ & 55.64 & 73.83 \\
\hline
\end{tabular}

${ }^{a}$ Media from 3 replicates; ${ }^{\mathrm{b}}$ Standard deviation from 3 replicates.

Table 2. Proximate composition of the in natura pulp/bark and almond of the butiá, Butia capitata ${ }^{1,2}$.

\begin{tabular}{lcc}
\hline \multicolumn{1}{c}{ Variables } & Raw pulp/bark & Almond \\
\hline Water content (\%) & $82.34 \pm 0.74$ & $24.46 \pm 0.6$ \\
Carbohydrates (\%) & $12.51 \pm 1.17$ & $31.92 \pm 4.61$ \\
Lipids (\%) & $3.42 \pm 0.43$ & $31.96 \pm 4.20$ \\
Proteins (\%) & $0.74 \pm 0.33$ & $10.58 \pm 0.05$ \\
Ash (\%) & $0.58 \pm 0.07$ & $1.34 \pm 0.03$ \\
Energy (kcal $\left.100 \mathrm{~g}^{-1}\right)$ & $83.34 \pm 0.27$ & $457.72 \pm 19.22$ \\
\hline
\end{tabular}

${ }^{1}$ Media from 3 replicates; ${ }^{2}$ Values in: media \pm standard deviation. 
(2013), The total caloric value ( $\left.83.34 \mathrm{kcal} 100 \mathrm{~g}^{-1}\right)$ was higher than that described by Sganzerla (2010), whose total caloric value was $53.21 \mathrm{kcal}$, which is explained by the high lipid content.

The butia almond presented high energy value, mainly due to its low humidity and high lipid content, when compared to the pulp. The lowest moisture content (9.9\%), and protein (10.58\%) and lipid content (31.96\%) values were higher than those observed in the present study (Faria et al., 2008b).

The variability between the results of the present study and those observed by other authors may be due to differences in the environmental, soil and climatic conditions of the fruit collection sites, as well as the population of plants analyzed. In a recent study, it was verified that the content of some micronutrients and bioactive compounds of Butia capitata varied according to these parameters (Magalhães et al., 2017). It should also be considered that the collected fruits had spontaneous growth, without antropic action in the growing conditions which can provide a natural variability among the samples.

\subsection{Vitamin C, vitamin E and carotenoids}

The content of vitamin C in the pulp of the butia (Table 3) was similar to that described by Faria et al. (2008a) in the pulp of this same fruit (53 mg. $100 \mathrm{~g} \mathrm{~g}^{-1}$ ) and at least $29 \%$ of fruits considered sources of this vitamin as orange (38.2 mg.100 g ${ }^{-1}$ ) and lemon (31 mg. $100 \mathrm{~g}^{-1}$ ) (Universidade Estadual de Campinas, 2011). The pulp can be considered a source of vitamin C (Brasil, 2012), since a portion ( $25 \mathrm{~g}$ ) can supply more than $15 \%$ of the recommendations of the DRI (Dietary Reference Intakes) of vitamin $C$ for children, preschoolers and (15-45 mg/day), adolescents (14-18 years) and adult and elderly women (19-> 70) (75 mg/day) (Institute of Medicine, 2000).

The pulp showed a high concentration of $\beta$-carotene $\left(8.56 \mathrm{mg}^{1} 100 \mathrm{~g}^{-1}\right)$, the only carotenoid identified among the four investigated. This content was approximately 4 times higher than that observed by Pereira et al. (2017), who also did not identify presence of $\beta$--carotene in the fruit pulp collected in the state of Rio Grande do Sul, Brazil. In addition, the observed content exceeds or approaches that of fruit sources of this compound as the mango (2.22 mg.100 g-1) (Ribeiro et al. (2007), papaya formosa (2.91 mg.100 g $\mathrm{g}^{-1}$ ), and inferior to the following fruits

Table 3. Contents of Carotenoids, Vitamin C, and Vitamin E in fresh pulp and almond of the butiá (Butia capitata) $)^{1,2}$.

\begin{tabular}{lcc}
\hline \multicolumn{1}{c}{ Vitamins } & Raw pulp/bark & Almond \\
\hline Vitamin $C\left(\mathrm{mg} .100 \mathrm{~g}^{-1}\right)$ & $53.57 \pm 4.55$ & $3.32 \pm 0.08$ \\
$\beta$-caroten $\left(\mathrm{mg} .100 \mathrm{~g}^{-1}\right)$ & $8.56 \pm 1.13$ & $1.83 \pm 0.20$ \\
Vitamin E $\left(\mu \mathrm{g} .100 \mathrm{~g} \mathrm{~g}^{-1}\right)$ & $121.07 \pm 10.7$ & $1594.39 \pm 428.83$ \\
$\alpha$-tocoferol $\left(\mu \mathrm{g} .100 \mathrm{~g}^{-1}\right)$ & $39.84 \pm 3.73$ & $81.20 \pm 5.58$ \\
$\alpha$-tocotrienol $\left(\mu \mathrm{g} .100 \mathrm{~g}^{-1}\right)$ & $28.02 \pm 5.89$ & $1036.02 \pm 71.15$ \\
$\gamma$-tocoferol $\left(\mu \mathrm{g} .100 \mathrm{~g}^{-1}\right)$ & $22.99 \pm 2.93$ & $53.09 \pm 5.80$ \\
$\gamma$-tocotrienol $\left(\mu \mathrm{g} .100 \mathrm{~g}^{-1}\right)$ & $11.11 \pm 1.02$ & $400.87 \pm 11.42$ \\
$\beta$-tocoferol $\left(\mu \mathrm{g} .100 \mathrm{~g}^{-1}\right)$ & $19.11 \pm 6.55$ & $23.21 \pm 2.15$ \\
\hline
\end{tabular}

${ }^{1}$ Media from 3 replicates; ${ }^{2}$ Values in: media \pm standard deviation. sweet passion fruit $\left(10.7 \mathrm{mg} \cdot 100 \mathrm{~g}^{-1}\right)$ and acerola $\left(10.45 \mathrm{mg} \cdot 100 \mathrm{~g}^{-1}\right)$ (Souza et al., 2004).

This was the first study to evaluate the vitamin E profile in Butiá capitata pulp and almond. Of the eight homologues in vitamin $\mathrm{E}$, five were identified in Butia capitata pulp and almond. Being a-tocopherol more prevalent, totaling $121.07 \mathrm{mcg} .100 \mathrm{~g} \mathrm{~g}^{-1}$. Compared with the cocuri pulp (Syagrus coronata), which presented $\alpha$-tocopherol $3.8 \mu \mathrm{g} . \mathrm{g}^{-1}$ (Crepaldi et al., 2001), the pulp of the sour coconut showed almost ten times higher contents of this nutrient.

Butia almonds had approximately 11 -fold higher vitamin E content than pulp, with $\alpha$-tocotrienol (approximately 65\%), $\gamma$-tocotrienol (approximately 25\%) and $\alpha$-tocopherol (approximately 5\%). The butiá almond presented higher total vitamin E content and vitamin E profile than Licuri (Syagrus coronata (Mart.) Becc) (Paula Filho et al., 2015). However, in both almonds the prevalence of tocotrienols was recorded in detriment of tocopherols. Some studies have shown that tocotrienols have superior antioxidant activity when compared to tocopherols. This antioxidant action, anti-inflammatory and cholesterol-lowering properties of tocotrienols can prevent cancers, diabetes and cardiovascular and neurodegenerative diseases (Sylvester et al., 2014). As for vitamin E, there are no studies on the carotenoid profile and vitamin C content in butyl almond. Almond of the sour coconut showed reduced contents of $\beta$-carotene and vitamin $C$, however, higher than those observed in coccus licuri (from Paula Filho et al., 2015).

\subsection{Minerals}

The mineral composition of the fresh pulp of the butia (Table 4 ) differed from that determined by Faria et al. (2008a), whose phosphorus (19.9 mg. $\left.100 \mathrm{~g} \mathrm{~g}^{-1}\right)$, calcium (16.8 mg. (12.5 mg.100 g $\left.{ }^{-1}\right)$ as described by this author was higher than that of potassium $\left(462,100 \mathrm{~g}^{-1}\right)$ and sulfur (7.3 mg.100 g $\left.\left.\mathrm{g}^{-1}\right) 4 \mathrm{mg} \cdot 100 \mathrm{~g}^{-1}\right)$.

Table 4. Mineral composition of the in natura pulp and almond of the butiá (Butia capitata) $)^{1,2}$.

\begin{tabular}{lrc}
\hline Minerals $\left(\mathrm{mg} .100 \mathrm{~g}^{-1}\right)$ & \multicolumn{1}{c}{ Pulp/bark } & \multicolumn{1}{c}{ Almond } \\
\hline Calcium & $19.40 \pm 0.23$ & $40.00 \pm 0.48$ \\
Iron & $1.60 \pm 0.03$ & $4.20 \pm 0.08$ \\
Magnesium & $10.80 \pm 0.43$ & $119.00 \pm 4.76$ \\
Manganese & $0.11 \pm 0.00$ & $1.20 \pm 0.01$ \\
Cupper & $1.80 \pm 0.07$ & $2.40 \pm 0.10$ \\
Molibdenium & $0.14 \pm 0.00$ & $0.90 \pm 0.01$ \\
Zinc & $0.20 \pm 0.00$ & $0.83 \pm 0.2$ \\
Sodium & $7.90 \pm 0.32$ & $24.80 \pm 0.99$ \\
Potassium & $430.10 \pm 5.16$ & $352.00 \pm 4.22$ \\
Crome & $0.01 \pm 0.00$ & $0.07 \pm 0.00$ \\
Phosphorus & $22.20 \pm 0.89$ & $301.00 \pm 12.04$ \\
Sulphur & $8.50 \pm 0.10$ & $120.00 \pm 1.44$ \\
\hline
\end{tabular}

${ }^{1}$ Media from 3 replicates; ${ }^{2}$ Values in: media \pm standard deviation. 
Table 5. Total phenolic compounds and antioxidant capacity of the pulp/bark and almond of the butiá (Butia capitata) $)^{1,2,3}$.

\begin{tabular}{lcc}
\hline \multicolumn{1}{c}{ Variables } & Pulp/bark & Almond \\
\hline $\begin{array}{l}\text { Total phenolic compounds } \\
\left(\text { mg Eq AC. } 100^{-1}\right)\end{array}$ & $493.6 \pm 23.30$ & $132.6 \pm 13.40$ \\
$\begin{array}{l}\text { Antioxidant activity }(\mu \mathrm{M} \\
\left.\text { trolox. g- }{ }^{-1}\right)\end{array}$ & $4.74 \pm 0.15$ & $0.4 \pm 0.05$ \\
\hline
\end{tabular}

${ }^{1}$ Values in fresh matter; ${ }^{2}$ Media from 3 replicates; ${ }^{3}$ Values in: media \pm standard deviation.

The almond presented concentrations of minerals superior to those found in the pulp, except for potassium. The concentration of almonds of Butia capitata when compared to almond of baru (Dipteryx alata Vog.) Showed an iron content (4.85 mg.100 g $\left.\mathrm{g}^{-1}\right)$ similar to the almond under study, lower levels of calcium (120.4 phosphorus (337.5 mg.100 g $\mathrm{g}^{-1}$ ) and manganese (7.02 mg.100 g $\mathrm{g}^{-1}$ ), zinc (3.66 mg.100 g-1), potassium (819 mg.100 g $\left.\mathrm{g}^{-1}\right)$ and higher values of sodium (3.30 mg.100 g-1) and copper (1.26 mg.100 g $\left.\mathrm{g}^{-1}\right)$ (Freitas \& Naves, 2010). The copper content in the almond of the sour coconut was superior to that described by Freitas \& Naves (2010), (1.26 mg.100 g $\mathrm{g}^{-1}$. This mineral is an important constituent of enzymes, acts on the immune system and confers protection against cardiovascular diseases (Panziera et al., 2011). A portion of approximately 6 fruits ( $36 \mathrm{~g}$ ) exceeds the recommendations of RDA of copper for all individuals over 1 year of age, of both sexes, as well as for mineral molybdenum (Institute of Medicine, 2001).

\subsection{Total phenolic compounds, anthocyanins and antioxidant capacity}

The total phenolic content in the butia pulp (Table 5) was higher than that reported by Sganzerla (2010) and Faria et al. (2008a), in pulp of the same fruit (260.41 and $116.3 \mathrm{mg} / 100 \mathrm{~g}$, respectively). This high value of total phenolic compounds can contribute to increase the intake of antioxidants in human food, since the intake of phenolic compounds in the diet was estimated between 0.15 and $1.0 \mathrm{~g} /$ day (Stahl et al, 2002). Anthocyanins were not found in the pulp, as well as in the study by Gonçalves (2008). The antioxidant capacity was determined in the fruit pulp and the result found was $4.74 \mu \mathrm{M}$ trolox. $\mathrm{g}^{-1}$, similar to the antioxidant capacity of extracts of pineapple, $4.8 \mu \mathrm{M}$ trolox.g ${ }^{-1}$ (Martínez et al., 2012).

\section{Conclusion}

The fruit of Butia capitata has good yield of pulp and high caloric value, due to the presence of lipids in expressive amounts. The pulp presents considerable amounts of vitamin C, $\beta$-carotene, copper and phenolic compounds, components considered important natural antioxidants. The almond also has considerable amounts of copper and molybdenum. Due to its nutritional value and abundance, the consumption of this fruit should be encouraged, since it is a source of nutrients and bioactive compounds, important for growth, development and protection against diseases.

\section{Acknowledgements}

The study was supported by the Brazilian agencies Conselho Nacional de Desenvolvimento Científico e Tecnológico (CNPq; http://www.cnpq.br/), (MCTI/CNPq n 480007/2013), Fundação de Amparo a Pesquisa do Estado de Minas Gerais - FAPEMIG, Financianadora de Estudos e Projetos (FINEP; http://www.finep. gov.br/), Pró-reitoria de Pós-graduação e Pesquisa da Universidade Federal de Juiz de Fora - Minas Gerais, Brasil (PROPP-UFJF).

\section{References}

Association of Official Analytical Chemists - AOAC. (1998). Official methods of analysis of the Association of Official Analytical Chemists (16th ed.). Washington: AOAC.

Bloor, S. (2001). Overview of methods for analysis and identification of flavonoids. Methods in Enzymology, 335, 3-14. http://dx.doi. org/10.1016/S0076-6879(01)35227-8. PMid:11400379.

Brasil, Agência Nacional de Vigilância Sanitária - Anvisa. (2003, December 26). Aprova regulamento técnico sobre rotulagem nutricional de alimentos embalados, tornando obrigatória a rotulagem nutricional (Resolução RDC n 360, de 23 de dezembro de 2003). Diário Oficial [da] República Federativa do Brasil.

Brasil, Agência Nacional de Vigilância Sanitária - Anvisa. (2012, November 13). Dispõe sobre o regulamento técnico sobre informação nutricional complementar (Resolução RDC no 54, de 12 de novembro de 2012). Diário Oficial [da] República Federativa do Brasil.

Cabral, T., Cardoso, L., \& Pinheiro-Sant'Ana, H. (2014). Chemical composition, vitamins and minerals of a new cultivar of lychee (Litchi chinensis cv. Tailandes) grown in Brazil. Fruits, 69(6), 425434. http://dx.doi.org/10.1051/fruits/2014031.

Campos, F., Ribeiro, S., Della Lucia, C., Pinheiro-sant'Ana, H., \& Stringheta, P. (2009). Optimization of methodology to analyze ascorbic and dehydroascorbic acid in vegetables. Química Nova, 32(1), 87-91. http://dx.doi.org/10.1590/S0100-40422009000100017.

Carvalho, I. (2007). Potenciais e limitações do uso sustentável da biodiversidade do Cerrado: Um estudo de caso da Cooperativa Grande Sertão no Norte de Minas. Revista Brasileira de Agroecologia, 2(2), 1449-1452.

Crepaldi, I. C., Almeida-Muradian, L. B. D., Rios, M. D. G., Penteado, M. D. V. C., \& Salatino, A. (2001). Composição nutricional do fruto de licuri (Syagrus coronata (Martius) Beccari). Brazilian Journal of Botany, 24(2), 155-159. http://dx.doi.org/10.1590/S0100-84042001000200004.

Ekholm, P., Reinivuo, H., Mattila, P., Pakkala, H., Koponen, J., Happonen, A., Hellström, J., \& Ovaskainen, M. (2007). Changes in the mineral and trace element contents of cereals, fruits and vegetables in Finland. Journal of Food Composition and Analysis, 20(6), 487-495. http:// dx.doi.org/10.1016/j.jfca.2007.02.007.

Faria, J., Almeida, F., Silva, L., Vieira, R., \& Agostini-Costa, T. (2008a). Caracterização da polpa do coquinho azedo (Butia capitata var capitata). Revista Brasileira de Fruticultura, 30(3), 827-829. http:// dx.doi.org/10.1590/S0100-29452008000300045.

Faria, J., Arellano, D., Grimaldi, R., Silva, L., Vieira, R., Silva, D., \& Agostini-Costa, T. (2008b). Caracterização química da amêndoa de coquinho-azedo (Butia capitata var capitata). Revista Brasileira de Fruticultura, 30(2), 549-552. http://dx.doi.org/10.1590/ S0100-29452008000200049.

Freitas, J., \& Naves, M. (2010). Composição química de nozes e sementes comestíveis e sua relação com a nutrição e saúde. Revista de Nutrição, 23(2), 269-279. http://dx.doi.org/10.1590/S1415-52732010000200010.

Fuleki, T., \& Francis, F. J. (1968). Quantitative methods for anthocyanins: 1. Extraction and determination of total anthocyanin in cranberries. Journal of Food Science, 33(1), 72-77. http://dx.doi. org/10.1111/j.1365-2621.1968.tb00887.x. 
Gonçalves, A. (2008). Avaliação da capacidade antioxidante de frutas e polpas de frutas nativas e determinação de teores de flavonoides e vitamina $C$ (Dissertação de mestrado). Faculdade de Ciências Farmacêuticas, Universidade de São Paulo, São Paulo. http://dx.doi. org/10.11606/D.9.2008.tde-28012009-161811.

Guinazi, M., Milagres, R., Pinheiro-Sant'Ana, H., \& Chaves, J. (2009). Tocoferois e tocotrienois em óleos vegetais e ovos. Química Nova, 32(8), 2098-2103. http://dx.doi.org/10.1590/S0100-40422009000800021.

Hoffmann, J., Barbieri, R., Rombaldi, C., \& Chaves, F. (2014). Butia spp. (Arecaceae): an overview. Scientia Horticulturae, 179, 122-131. http://dx.doi.org/10.1016/j.scienta.2014.08.011.

Institute of Medicine - IOM. (2000). Dietary reference intake: applications in dietary assessment. Washington, DC: National Academy Press.

Institute of Medicine - IOM. (2001). Dietary reference intakes for vitamin $A$, vitamin $K$, arsenic, boron, chromium, copper, iodine, iron, manganese, molybdenium, nickel, silicon, vanadium and zinc. Washington, DC: National Academy Press.

Lopes, R., Silva, J., Vieira, R., Silva, D., Gomes, I., \& Agostini-Costa, T. (2012). Composição de ácidos graxos em polpa de frutas nativas do Cerrado. Revista Brasileira de Fruticultura, 34(2), 635-640. http:// dx.doi.org/10.1590/S0100-29452012000200041.

Magalhães, H. M., Brandão, T. M., Stracieri, J., Jesus, H. F., Mendes, D. S. T., \& Pasqual, M. (2017). Evaluating chemical composition of Butia capitata pulp among various populations and locations using multivariate analysis. African Journal of Biotechnology, 16(38), 19021910. http://dx.doi.org/10.5897/AJB2017.16107.

Magalhães, H., Catão, H., Sales, N., Lima, N., \& Lopes, P. (2008). Qualidade sanitária de sementes de coquinho-azedo (Butia capitata) no Norte de Minas Gerais. Ciência Rural, 38(8), 2371-2374. http:// dx.doi.org/10.1590/S0103-84782008000800045.

Martínez, R., Torres, A., Meneses, M. A., Figueroa, J. G., Pérez-Álvarez, J. A., \& Viuda-Martos, M. (2012). Chemical, technological and in vitro antioxidant properties of mango, guava, pineapple and passion fruit dietary fibre concentrate. Food Chemistry, 135(3), 1520-1526. http://dx.doi.org/10.1016/j.foodchem.2012.05.057. PMid:22953888.

Moura, R., Lopes, P., Brandão, D. Jr., Gomes, J., \& Pereira, M. (2010). Biometria de frutos e sementes de Butia capitata (Mart.) Beccari (Arecaceae), em vegetação natural no Norte de Minas Gerais, Brasil. Biota Neotropica, 10(2), 415-419. http://dx.doi.org/10.1590/S167606032010000200040.

Panziera, F., Dorneles, M., Durgante, P., \& Silva, V. (2011). Avaliação da ingestão de minerais antioxidantes em idosos. Revista Brasileira de Geriatria e Gerontologia, 14(1), 49-58. http://dx.doi.org/10.1590/ S1809-98232011000100006.

Paula Filho, G. X., Barreira, T. F., Rodrigues, V. C. C., Cardoso, L. M., Martino, H. S. D., \& Pinheiro-Sant'Ana, H. M. (2015). Study of the physical and physicochemical characteristics of fruits of the licuri palm (Syagrus coronata (Mart.) Becc.) found in the Atlantic Forest of Minas Gerais, Brazil. Food Science and Technology (Campinas), 35(3), 474-480. http://dx.doi.org/10.1590/1678-457X.6652.

Peralta, S. L., Carvalho, P. H., van de Sande, F. H., Pereira, C. M., Piva, E., \& Lund, R. G. (2013). Self-etching dental adhesive containing a natural essential oil: anti-biofouling performance and mechanical properties. Biofouling, 29(4), 345-355. http://dx.doi.org/10.1080/0 8927014.2013.770477. PMid:23560741.
Pereira, G. S., Braga, R. N., Souza, H. F., Oliveira, M.L.P., Lima, J.P., \& Vieira, C.R. (2017). Análises físico-químicas e tecnológicas em massa alimentícia fresca incorporada de farinha de coquinho-azedo (Butia capitata). Caderno Ciências Agrárias, 9(3),01-05.

Pereira, M. C., Steffens, R. S., Jablonski, A., Hertz, P. F., Rios, A. O., Vizzotto, M., \& Flôres, S. H. (2013). Characterization, bioactive compounds and antioxidant potential of three Brazilian fruits. Journal of Food Composition and Analysis, 29(1), 19-24. http:// dx.doi.org/10.1016/j.jfca.2012.07.013.

Pinheiro-Sant'Ana, H. M., Stringheta, P. C., Brandão, S. C. C., \& Azeredo, R. M. C. (1998). Carotenoid retention and vitamin A value in carrot (Daucus carota L.) prepared by food servisse. Food Chemistry, 61(1-2), 145-151. http://dx.doi.org/10.1016/ S0308-8146(97)00084-8.

Ribeiro, S., Queiroz, J., Queiroz, M., Campos, F., \& Pinheiro Sant'Ana, H. (2007). Antioxidant in Mango (Mangifera indica L.) pulp. Plant Foods for Human Nutrition, 62(1), 13-17. http://dx.doi.org/10.1007/ s11130-006-0035-3. PMid:17243011.

Rodriguez-Amaya, D., Kimura, M., \& Amaya-Farfan, J. (2008). Fontes brasileiras de carotenóides: tabela brasileira de composição de carotenóides em alimentos. Brasília: Ministério do Meio Ambiente.

Schwartz, E., Fachinello, J., Barbieri, R., \& Silva, J. (2010). Avaliação de populações de Butia capitata de Santa Vitória do Palmar. Revista Brasileira de Fruticultura, 32(3), 736-745. http://dx.doi.org/10.1590/ S0100-29452010005000089.

Sganzerla, M. (2010). Caracterização físico-química e capacidade antioxidante do butiá (Dissertação de mestrado). Programa de Pósgraduação em Ciência e Tecnologia Agroindustrial, Faculdade de Agronomia Eliseu Maciel, Universidade Federal de Pelotas, Pelotas.

Slavin, J., \& Lloyd, B. (2012). Health benefits of fruits and vegetables. Advances in Nutrition, 3(4), 506-516. http://dx.doi.org/10.3945/ an.112.002154. PMid:22797986.

Souza, S. L., Moreira, A. P. B., Sant'Ana, H. M. P., \& Alencar, E. R. (2004). Conteúdo de carotenos e provitamina A em frutas comercializadas em Viçosa, Estado de Minas Gerais. Acta Scientiarum. Agronomy, 26(4), 453-459. http://dx.doi.org/10.4025/ actasciagron.v26i4.1807.

Stahl, W., Van Den Berg, H., Arthur, J., Bast, A., Dainty, J., Faulks, R. M., Gärtner, C., Haenen, G., Hollman, P., Holst, B., Kelly, F. J., Polidori, M. C., Rice-Evans, C., Southon, S., van Vliet, T., ViñaRibes, J., Williamson, G., \& Astley, S. B. (2002). Bioavailability and metabolism. Molecular Aspects of Medicine, 23(1-3), 39-100. http:// dx.doi.org/10.1016/S0098-2997(02)00016-X. PMid:12079770.

Sylvester, P. W., Akl, M. R., Malaviya, A., Parajuli, P., Ananthula, S., Tiwari, R. V., \& Ayoub, N. M. (2014). Potential role of tocotrienols in the treatment and prevention of breast câncer. BioFactors, 40(1), 49-58. http://dx.doi.org/10.1002/biof.1116. PMid:23804535.

Universidade Estadual de Campinas - Unicamp. (2011). Tabela Brasileira de Composição de Alimentos (TACO). Campinas. Retrieved from http:// www.unicamp.br/nepa/taco/contar/taco_4_edicao_ampliada_e_ revisada.pdf?arquivo=ta co_4_versao_ampliada_e_revisada.pdf

Vieira, R., Costa, T., Silva, D., Ferreira, F., \& Sano, S. (2006). Frutas nativas da região Centro-Oeste do Brasil. Brasília: Embrapa. 